\title{
A Genome Scan for Quantitative Trait Loci Affecting Milk Production in Norwegian Dairy Cattle
}

\author{
H. G. Olsen*, L. Gomez-Raya†, D. I. Våge*, I. Olsakerł, H. Klungland*, M. Svendsen*, \\ T. Ådnøy*, A. Sabry*, G. Klemetsdal*, N. Schulman§, W. Krämer\|, G. Thaller\|, \\ K. Rønningen‡ and S. Lien* \\ *Department of Animal Science, Agricultural University of Norway, \\ $\mathrm{N}-1432$ Aas, Norway \\ †Centre UdL-IRTA, Department of Animal Production, \\ 25198 Lleida, Spain \\ ‡Department of Morphology, Genetics and Aquatic Biology, \\ The Norwegian School of Veterinary Science, N-0033 Oslo, Norway \\ $\S$ Agricultural Research Centre MTT, Animal Production Research, \\ 31600 Jokioinen, Finland \\ |Chair of Animal Breeding, Technical University of Munich, \\ D-85380 Freising-Weihenstephan, Germany
}

\begin{abstract}
An autosomal genome scan for quantitative trait loci (QTL) affecting milk production traits was carried out on the Norwegian Dairy Cattle population. Six halfsibling families with a total of 285 sons organized according to a granddaughter design were analyzed by a multiple marker regression method. Suggestive QTL for one or several of the five milk traits (milk yield, protein percentage, protein yield, fat percentage and fat yield) were detected on chromosomes $3,5,6,11$, 13, 18 and 20. Among these results, the findings on chromosomes 3,6 , and 20 are highly supported by literature. The most convincing result was found close to marker FBN9 on chromosome 6, where a QTL was detected with alleles that cause a marked reduction in both protein and fat percentages and an increase in milk yield. The results for fat and protein percentage were highly significant even after accounting for multiple testing across the genome. Using bootstrapping, a 95\% confidence interval for the position of the QTL for the percentage traits on chromosome 6 was estimated to $16 \mathrm{cM}$.
\end{abstract}

(Key words: quantitative trait loci, milk, cattle)

Abbreviation key: BTA = bovine (Bos taurus) chromosome, $\mathbf{C I}=$ confidence interval, $\mathbf{E B V}=$ estimated breeding value, $\mathbf{N C M}=$ Norwegian Dairy Cattle Map.

\section{INTRODUCTION}

Much effort has been undertaken worldwide to generate highly polymorphic markers in livestock (Barendse

Received February 16, 2002.

Accepted May 24, 2002.

Corresponding author: Hanne Gro Olsen; e-mail: hanne-gro.olsen@ ihf.nlh.no. et al., 1997; Kappes et al., 1997). This activity has provided sufficient marker density to perform genome scans of populations for QTL affecting economically important traits. The granddaughter design (Weller et al., 1990) has proved to be an efficient scheme for QTL mapping in cattle. By use of this design, a number of studies have reported the presence of significant QTL affecting milk production traits (Georges et al., 1995; Spelman et al., 1996; Coppieters et al., 1998; Heyen et al., 1999; Kühn et al., 1999; Velmala et al., 1999; de Koning et al., 2001; Nadesalingam et al., 2001). Although some reported QTL show effects large enough for utilization in selection programs, the resolution achieved by a genome scan is rather poor and usually insufficient for positional cloning of the corresponding gene. As certainty about QTL positions and effects is difficult to achieve in any single population, results from studies in different breeds should be compared in order to identify chromosomal regions harboring QTL.

Recently, a male genetic marker map based on six paternal half-sib families from the Norwegian Dairy Cattle population has been constructed (Våge et al., 2000). The aim of the present work was to use the genotypic information of these six families in an autosomal genome scan for QTL affecting milk production traits in the Norwegian Dairy Cattle population.

\section{MATERIALS AND METHODS}

\section{Animals}

All animals in the study belonged to the Norwegian Dairy Cattle breed, which is a dual-purpose breed originally formed by the fusion of local Norwegian breeds and a significant import of Ayrshire, Swedish Red-andWhite and Holstein from the 1960s onward (Felius, 1995). 
Table 1. ID number and names of the six sires used in the QTL study, number of sons per sire family and average number of daughters per son.

\begin{tabular}{llc}
\hline Sire ID & $\begin{array}{l}\text { Number of } \\
\text { sons per sire }\end{array}$ & $\begin{array}{l}\text { Average number of } \\
\text { daughters per son }\end{array}$ \\
\hline 2005 Smidesang & 71 & 878 \\
2052 Mauland & 32 & 1253 \\
2402 Thorset & 54 & 862 \\
2463 Jørgentvedt & 39 & 1081 \\
2946 Bekkevold & 42 & 532 \\
3131 Okkelberg & 47 & 562 \\
\hline
\end{tabular}

For the present study, six paternal half-sib families were chosen because of their relatively large number of progeny-tested sons. The total number of sons in the study were 284 , ranging from 32 sons of sire 2052 to 71 sons of sire 2005 (Table 1). The average number of effective daughters in the dataset was as large as 843, and only one son had less than 150 daughters.

Complex relationships exist between the animals. Most important, sires 2005 and 2052, as well as sires 2402 and 2463, are paternal half-sibs. As many of the sons are also related through their dams, most of the animals are related to some degree.

\section{Marker Map}

The Norwegian Cattle Map (NCM) covers all 29 autosomal chromosomes and summarizes to a total length of $2682 \mathrm{cM}$ (Våge et al., 2000). The map consists of 288 markers, with an average of 131 informative sons per marker. The average length of marker intervals is 12.5 $\mathrm{cM}$, and approximately $82 \%$ of the intervals are shorter than $20 \mathrm{cM}$. The chromosome assignment, locus order and interval lengths agree with the most comprehensive linkage map available in cattle (Kappes et al., 1997). The marker map was constructed using six halfsib families (Table 1), with marker information for sires and their sons only. Detailed information about the NCM is available at http://www.nlh.no/Institutt/IHF/ Genkartstorfe/.

The marker density of the NCM was increased for chromosome 6 by genotyping four additional microsatellites (FBN9, FBN12, FBN13 and FBN15) with primers and PCR conditions as described by Weikard et al. (1997). Linkage order and map distances among markers were estimated using the CRI-MAP 2.4 program (Green et al., 1990), with map distances based on Haldane's mapping function.

\section{Performance Data}

In Norway, progeny testing is based on more than 250 daughters per son, which is about five times higher than commonly used in other European or American populations. Estimated breeding values (EBV) of the sons from the six families were used for performance data in the analyses. EBV for the five milk production traits (milk yield, fat percentage, fat yield, protein percentage and protein yield) were available from the national genetic evaluation in June 2000 carried out by GENO Breeding and A.I. Association, and evaluated using BLUP with a single trait sire-maternal grandsire model.

\section{Statistical Analyses}

The multiple marker regression method described by de Koning et al. (2001) was applied for QTL mapping. As the method assumes that all sires and dams are unrelated, and that each dam has only one offspring, information about the extensive relationships between animals was not included in the analysis. A weighted least squares analysis was utilized, where the weights were the number of daughters per son.

First, the most likely linkage phase of each of a sire's chromosomes was estimated based on marker information of the sire and his sons. For a given heterozygous marker, the allele inherited from sire to son could be determined unequivocally if the son possessed only one of the sire's alleles. If the son was heterozygous for the same alleles as his sire, the most likely paternal allele was estimated from the flanking markers. The most likely haplotype of the sire was taken as the linkage phase minimizing the number of recombinant offspring. One of the haplotypes of each chromosome of the sire was arbitrarily chosen as the first haplotype. Then, for each son, the probability of inheriting the sire's first haplotype was calculated at each cM along each chromosome conditional on informative flanking markers.

At each cM, a QTL was fitted using least squares methodology by regressing the trait score of the individual on the probability of receiving the first haplotype at that point, according to the model:

$$
\mathrm{Y}_{\mathrm{ij}}=\mu+\mathrm{a}_{\mathrm{i}}+\mathrm{b}_{\mathrm{i}} \mathrm{X}_{\mathrm{ij}}+\mathrm{e}_{\mathrm{ij}}
$$

where

$$
\begin{aligned}
\mathrm{Y}_{\mathrm{ij}}= & \text { EBV of son } \mathrm{j} \text { within sire family } \mathrm{i}(\mathrm{i}=1 \text { to } \\
& 6) ; \\
\mu= & \text { overall mean; } \\
\mathrm{a}_{\mathrm{i}}= & \text { fixed polygenic effect of sire } \mathrm{i} ; \\
\mathrm{b}_{\mathrm{i}}= & \text { regression coefficient within sire } \mathrm{i} \text {; (i.e. al- } \\
& \text { lele substitution effect for a putative QTL) } \\
\mathrm{X}_{\mathrm{ij}}= & \text { probability of son } \mathrm{j} \text { of inheriting the first } \\
& \text { haplotype from sire i conditional on the } \\
& \text { informative flanking markers of the son; } \\
& \text { and }
\end{aligned}
$$




$$
\mathrm{e}_{\mathrm{ij}}=\text { residual effect. }
$$

This model assumed one QTL with an additive effect and no interaction because dominance cannot be detected using a half-sib structure, and because detection of epistasis would require several QTL. The residual effects were assumed normally distributed.

Regression was nested within sire because the QTL and marker alleles as well as their respective linkage phases might be different across sires. For each sire, a within-family test statistic for the regression coefficients was calculated at each $\mathrm{cM}$ along the genome, and the position with the maximum F-ratio was considered to be the most likely QTL location for that family. An across-family F-ratio was then obtained by pooling the regression mean squares over grandsires and dividing it by the residual mean squares. Again, this analysis was repeated at each position along the genome to find an estimate of the overall best position. The across family test statistic was used for determining whether a QTL was segregating in the tested material, and to find the most likely overall position for this QTL. The within-family test statistic revealed which families were heterozygous for the QTL, and could give an indication of whether one of more QTL were segregating if the most likely QTL position differed between families.

Chromosome-wise significance values $\left(P_{\text {chromosome }}\right)$ for both the within-family and the across-family analyses were determined empirically applying the permutation test of Churchill and Doerge (1994), with 10,000 permutations per chromosome. As performing a full permutation test for all 29 chromosomes simultaneously was too computer demanding, the genome-wise significance levels, taking into account the multiple testing of the entire genome, were derived by a Bonferroni correction as:

$$
P_{\text {genome }}=1-\left(1-P_{\text {chromosome }}\right)^{1 / r},
$$

where $P_{\text {chromosome }}$ is the significance level of a specific chromosome and $r$ was obtained as the length of the specific chromosome divided by the total length of the autosomal genome (de Koning et al., 1999).

Empirical 95\% confidence intervals (CI) for the QTL positions were obtained by applying the bootstrapping approach proposed by Visscher et al. (1996).

In addition, chromosome 6 was tested for the presence of two QTL as described by Velmala et al. (1999). A model testing the presence of two QTL vs. none was fitted as:

$$
\mathrm{Y}_{\mathrm{ij}}=\mu+\mathrm{a}_{\mathrm{i}}+\mathrm{b}_{\mathrm{i} 1} \mathrm{X}_{\mathrm{ij} 1}+\mathrm{b}_{\mathrm{i} 2} \mathrm{X}_{\mathrm{ij} 2}+\mathrm{e}_{\mathrm{ij}} \text {, }
$$

where the subscripts 1 and 2 refer to the position of the first and the second QTL, respectively, and the other terms are the same as for the one-QTL model. The two-QTL model was fitted by grid searching, i.e. each combination of 5-cM positions was tested with a minimum distance of $10 \mathrm{cM}$ between the two intervals. The most probable positions of the two QTL were taken as the combination giving the highest F-value. Empirical significance values were determined by permutation. If the test statistic for two vs no QTL was significant, the presence of two vs one QTL was tested with an F-test on the mean squares from the two-QTL model compared to that of the best one-QTL model. Whether the two-QTL model explained more of the variation than the one-QTL model was evaluated from a standard $\mathrm{F}$ table, with the number of grandsires as nominator and the total number of sons minus three times the number of grandsires as the denominator (Velmala et al, 1999).

\section{RESULTS}

The genome scan for quantitative trait loci affecting milk production in Norwegian Dairy Cattle revealed putative QTL on chromosomes (BTA) 3, 5, 6, 11, 13, 18 and 20 (Table 2). A highly significant QTL for protein $\left(P_{\text {genome }}<10^{-5}\right)$ and fat $\left(P_{\text {genome }}<10^{-5}\right)$ percentages was found in the middle of chromosome 6 , close to marker FBN9 (Figure 1). The analysis also suggested that a QTL affecting milk yield $\left(P_{\text {chromosome }}=0.02\right)$ could be positioned to the same region. However, no significant segregation of QTL for fat or protein yield was detected.

For the putative QTL on chromosome 6 affecting the percentage traits, two out of six families were segregating. The sires of these two families, 2402 and 2463, were paternal half-sibs carrying an identical marker haplotype in the relevant chromosomal region. In both families, the shared haplotype reduced fat and protein percentages, but increased milk yield, which is in accordance with the generally accepted negative genetic correlation between these traits.

Rather large QTL effects were detected for both percentage traits. The allele substitution effect on protein percentage was estimated to be approximately $0.16 \%$ and $0.20 \%$ (1.6 and 1.9 genetic standard deviations) in family 2402 and family 2463 , respectively, whereas the effect on fat percentage was approximately $0.17 \%$ and $0.42 \%$ ( 0.8 and 2.1 genetic standard deviations) in the same two families. Segregation of QTL for milk yield was detected only in family 2463 , with an allele substitution effect of approximately $350 \mathrm{~kg}$ milk, or 0.85 genetic standard deviations.

Confidence intervals for the most likely QTL positions on chromosome 6 were estimated by a bootstrap- 
Table 2. The most likely positions of the putative QTL for milk production in the across-family genome scan, and their corresponding significance levels.

\begin{tabular}{lcclccc}
\hline Trait $^{1}$ & Chromosome & Position & Marker interval & F-value & $\mathrm{P}_{\text {chromosome }}$ & $\mathrm{P}_{\text {genome }}{ }^{2}$ \\
\hline MY & 6 & 37 & FBN12-BM143 & 3.74 & 0.019 & NS \\
& 18 & 39 & INRA121-BM7109 & 4.58 & 0.003 & 0.08 \\
F\% & 5 & 120 & UW48-ETH152 & 4.90 & 0.009 & NS \\
& 6 & 41 & FBN9-FBN13 & 11.76 & $<10^{-7}$ & $<10^{-5}$ \\
FY & 3 & 14 & FCGR3-EAL & 3.73 & 0.014 & $\mathrm{NS}$ \\
& 5 & 115 & BM1819-UW48 & 3.69 & 0.018 & $\mathrm{NS}$ \\
& 11 & 83 & HUJV174-ILSTS45 & 3.71 & 0.014 & $\mathrm{NS}$ \\
P\% & 6 & 41 & FBN9-FBN13 & 16.38 & $<10^{-7}$ & $<10^{-5}$ \\
& 13 & 32 & BMC1222-BMS1352 & 4.62 & 0.005 & $\mathrm{NS}$ \\
PY & 18 & 79 & ILSTS2-EAC & 3.47 & 0.018 & $\mathrm{NS}$ \\
& 20 & 66 & BMS2361-UWCA26 & 3.05 & 0.037 & $\mathrm{NS}$ \\
\hline
\end{tabular}

${ }^{1} \mathrm{MY}=$ milk yield, $\mathrm{F} \%$ = fat percentage, $\mathrm{FY}=$ fat yield, $\mathrm{P} \%$ = protein percentage, $\mathrm{PY}=$ protein yield.

${ }^{2} \mathrm{NS}=$ not significant.

ping approach. The 95\% CI for the two percentage traits were almost identical in position and size, covering positions 29 to $45 \mathrm{cM}$ for fat percentage and positions 30 to 46 for protein percentage. An overlapping, but much wider, confidence interval was found for milk yield, encompassing positions 22 through 128.

For the other chromosomes, a putative QTL affecting milk yield on BTA18 was the most significant, with a

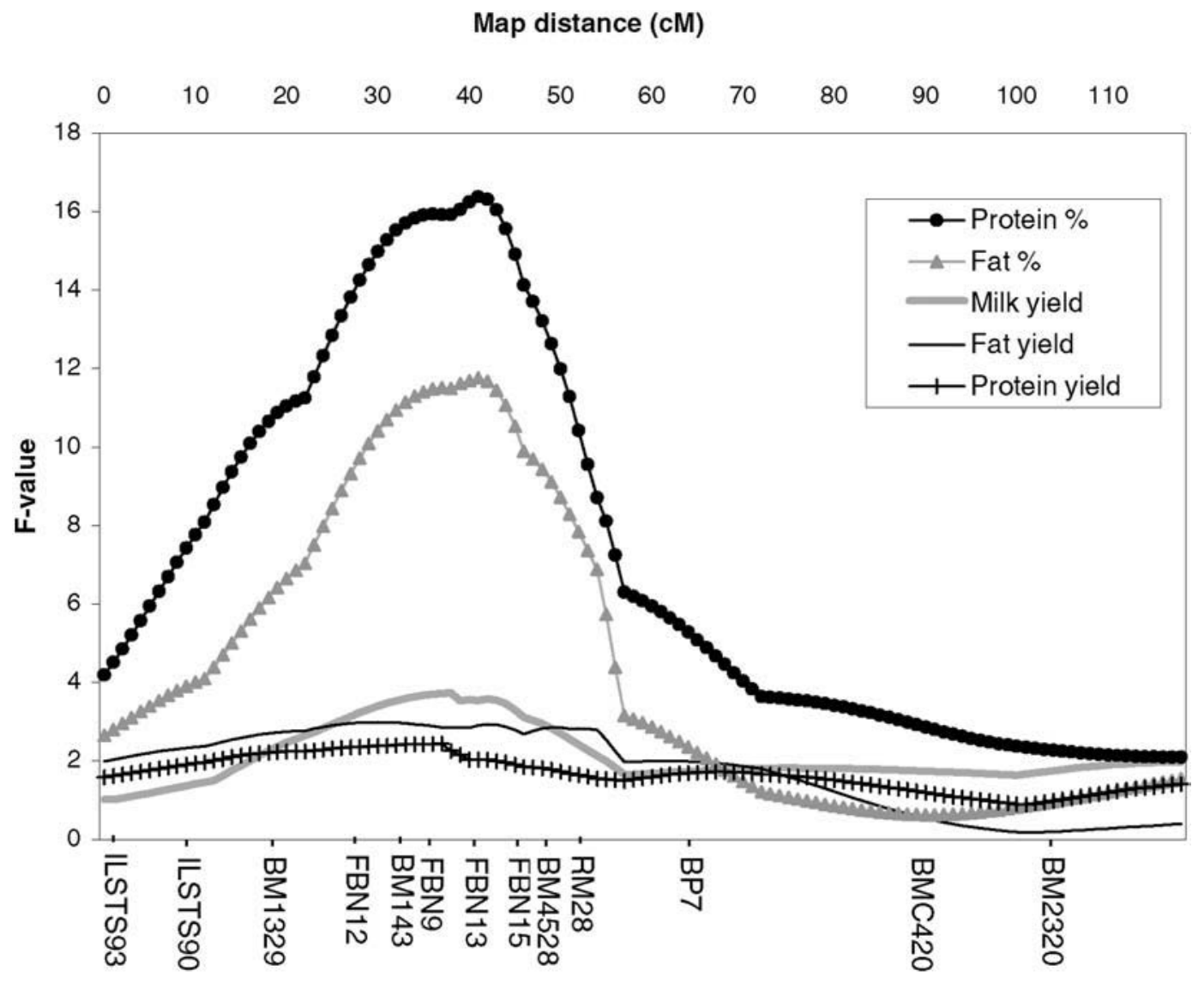

Figure 1. Across-family QTL results for milk production traits on bovine chromosome 6 in the Norwegian Dairy Cattle population. Markers are pointed out on the lower X-axis and map distances in cM from the centromere are shown on the upper X-axis. $\mathrm{F}$-values are shown on the Y-axis. 
genome-wise significance level of $8 \%$. Although segregation was detected in one family only, the substitution effect in this family corresponded to approximately 396 $\mathrm{kg}$ or 0.96 genetic standard deviations.

\section{DISCUSSION}

The results of this study strongly indicate the presence of a QTL close to marker FBN9 in the middle of chromosome 6 , which increases milk yield and reduces fat and protein percentages. In our map, FBN9 is located only $2 \mathrm{cM}$ telomeric of marker BM143, for which studies of several Holstein populations have reported a QTL with similar effects (e.g. Georges et al., 1995; Spelman et al., 1996; Zhang et al., 1998; Kühn et al., 1999; Ron et al., 2001). Similar results have also been found for Finnish Ayrshire (Velmala et al., 1999). Since the 1960's, there has been an extensive import of semen from Holstein-Friesian, Finnish Ayrshire, and Swedish Red-and-White bulls, and also a significant export of semen from Norwegian Dairy Cattle bulls to Sweden and Finland. Because of the considerable number of relationships between these breeds, it is possible that the results reflect the presence of the same QTL inherited identical-by-descent from a common ancestor.

The common haplotype surrounding the BTA6 QTL found in families 2402 and 2463 seems to cause a marked reduction in fat and protein percentages, and a modest increase in milk yield. Such an effect might be explained by gene(s) affecting the lactose yield. As lactose is the major osmotic component of the milk, increased lactose yield would result in increased milk yield, but unaltered yield of fat and protein. Thus, fat and protein percentages would be reduced. However, there are no indications that genes with such effects are present in the relevant area of BTA6.

Unfavorable genetic correlation between increased milk production and enhanced frequency of mastitis is well known. In a recent study of the same families (Klungland et al., 2001), putative QTL affecting clinical mastitis were localized to BTA3, 4, 6, 14 and 27, respectively. Whereas the mastitis BTA3 QTL is positioned on the other end of the chromosome, the BTA6 QTL has similar location for both traits. Based on these findings it could be argued that the mastitis QTL on BTA6 is caused by high milk yield, rather than a change in the immune response or, alternatively, that the relatively wide confidence interval for the mastitis QTL could contain several independent QTL. The fact that the QTL for milk production and clinical mastitis were detected in different families supports the latter hypothesis.

Several studies have reported another QTL on chromosome 6 , which is close to the casein gene cluster (e.g.
Kühn et al., 1996; Velmala et al., 1999). As a previous study in Norwegian Dairy Cattle also reported an association between protein yield and a specific casein haplotype (Lien et al., 1995), a test for the presence of two QTL on chromosome 6 was performed. However, no support for a second QTL in the casein region was found. A possible explanation for this discrepancy may be, in addition to the use of different statistical approaches, that the animal material was somewhat different in the two studies.

In recent years, a large number of breeds have been tested for the presence of QTL using an array of different methods. From these studies, as many as 20 chromosomes have been suggested to harbor QTL that affect milk traits (Mosig et al. 2001). Typically, only a few of the putative QTL detected in a given study are confirmed by other studies. Of the putative QTL reported in this study, the findings on chromosomes 3 and 20 are strongly supported by the literature. On BTA3, one family was segregating for a putative QTL affecting fat yield near the centromere. Previously, Heyen et al. (1999) found significant marker effects for at least one QTL affecting fat percentage, protein yield and protein percentage in the same region in the US Holstein population. Lipkin et al. (1998) and Zhang et al. (1998) also reported a QTL for protein percentage at the centromeric end of BTA3. On BTA20, a QTL affecting protein yield was segregating in one family in our study, between markers BMS2361 and UWCA26. This confirms the results found in Holstein (Arranz et al., 1998; Georges et al., 1995; Zhang et al., 1998) and in Finnish Ayrshire (Mäki-Tanila et al., 1998). Although the across-family test statistic for BTA3 and BTA20 did not exceed the genome-wise significance level in our study, the presence of similar patterns in different studies strongly support these positions as putative QTL for milk production traits. Other studies have reported the presence of QTL on chromosomes showing no significant effect in this study, e.g. BTA1 (e.g. Georges et al., 1995; Nadesalingam et al., 2001), BTA9 (Georges et al., 1995; Vilkki et al., 1997; Zhang et al., 1998; Wiener et al., 2000) and BTA14 (e.g. Coppieters et al., 1998; Heyen et al., 1999). The BTA14 QTL has later been finemapped (Riquet et al., 1999; Looft et al, 2001), and a candidate gene and a causal mutation have been detected (Grisart et al., 2001). This inconsistency across studies can partly be explained by the many different statistical methods and designs used in the studies, and by how the significance thresholds are set to account for the multiple testing performed in each study. For most breeds, family sizes are lower than optimum for QTL detection, thus detection power is low in most studies. As a consequence, many QTL are missed, and the effect of those detected is often overestimated. Addi- 
tionally, as most QTL are segregating in only a few families, the sires in the studied sample might not be heterozygous for a QTL segregating in the population as a whole. The density and informativity of the surrounding markers could also be insufficient for linkage detection. Confirmation of results in independent studies is therefore needed to reveal which effects are authentic. Importantly, analysis of data from different breeds or populations might also provide additional insight into the genetics controlling the trait of interest.

Most genome scans using similar experimental designs report confidence intervals of at least 20 to $30 \mathrm{cM}$. Thus, the $16 \mathrm{cM}$ intervals estimated for the percentage traits on BTA6 are surprisingly narrow, a fact that probably reflects the large effect of the QTL. These intervals, however, cannot be substantially reduced by denser marker maps due to the lack of recombinations needed for positioning the QTL. Marker information may be utilized in e.g., marker-assisted selection, separating linked QTL, estimation of pleiotropic effects and positional cloning. However, these implementations require the QTL to be mapped to an interval of 1 to 2 cM to be efficient. Other methods with much higher precision than the genome scan are therefore needed.

A more precise location of the QTL could be achieved by identifying additional families segregating the QTL and increase the number of genotyped sons within these families. This is not a realistic approach in Norwegian Dairy Cattle, however, as the number of sire families with a large number of progeny-tested sons is limited. Alternatively, the granddaughter design could be supplemented by genotyping a very large number of daughters in a daughter design. Recently, Ron et al. (2001) were able to confine a QTL for protein percentage on BTA6 to a confidence interval of only $4 \mathrm{cM}$ for two families of the Israeli Holstein population by using this approach. However, this approach is not easily applicable to the Norwegian Dairy Cattle population as herd size is small, making the collection of DNA samples very expensive. Thus, a more realistic approach for increasing the precision of the estimates is to utilize historical recombinations in linkage disequilibrium or identical by descent mapping (Meuwissen et al., in press; Riquet et al., 1999) to refine the location of the BTA6 QTL in Norwegian Dairy Cattle. When reaching an acceptable refinement, the QTL positions can be compared with comparative regions of the human genome in an effort to identify positional candidate genes.

For the putative QTL on bovine chromosomes 3 and 6 , no obvious candidate genes for milk production were identified by examination of the corresponding human genome information. On chromosome 20, however, the genes encoding the prolactine and growth hormone receptors are mapped to the same interval as was reported in this and other studies, and are therefore possible candidates for further research.

\section{CONCLUSION}

A QTL with a highly significant effect on milk production was detected on chromosome 6 in Norwegian Dairy Cattle. The most likely position of this QTL is between markers FBN9 and FBN13, with a 95\% confidence interval of $16 \mathrm{cM}$. The QTL causes an increase in milk yield and reduction of fat and protein percentages.

\section{ACKNOWLEDGMENTS}

We thank Dirk-Jan de Koning for providing the regression analysis program, GENO Breeding and A.I. Association for providing relationship information, and EBV for sons. The project has received funding from the Research Council of Norway and GENO Breeding and A.I. Association.

\section{REFERENCES}

Arranz, J. J., W. Coppieters, P. Berzi, N. Cambisano, B. Grisart, L. Karim, F. Marcq, L. Moreau, C. Mezer, J. Riquet, P. Simon, P. Vanmanshoven, D. Wagenaar, and M. Georges. 1998. A QTL affecting milk yield and composition maps to bovine chromosome 20: a confirmation. Anim. Genet. 29:107-115.

Barendse, W., D. Vaiman, S. J. Kemp, Y. Sugimoto, S. M. Armitage, J. L. Williams, H. S. Sun, A. Eggen, M. Agaba, S. A. Aleyasin, M. Band, M. D. Bishop, J. Buitkamp, K. Byrne, F. Collins, L. Cooper, W. Coppieters, B. Denys, R. D. Drinkwater, K. Easterday, C. Elduque, S. Ennis, G. Erhardt, and L. Li, et al. 1997. A mediumdensity genetic linkage map of the bovine genome. Mamm. Genome 8:21-28.

Churchill, G. A., and R. W. Doerge. 1994. Empirical threshold values for quantitative trait mapping. Genetics 138:963-971.

Coppieters, W., J. Riquet, J. J. Arranz, P. Berzi, N. Cambisano, B. Grisart, L. Karim, F. Marcq, L. Moreau, C. Nezer, P. Simon, P. Vanmanshoven, D. Wagenaar, and M. Georges. 1998. A QTL with major effect on milk yield and composition maps to bovine chromosome 14. Mamm. Genome 9:540-544.

de Koning, D. J., L. L. Janss, A. P. Rattink, P. A. van Oers, B. J. de Vries, M. A. Groenen, J. J. van der Poel, P. N. de Groot, E. W. Brascamp, and J. A. van Arendonk. 1999. Detection of quantitative trait loci for backfat thickness and intramuscular fat content in pigs (Sus scrofa). Genetics 152:1679-1690.

de Koning, D. J., N. F. Schulman, K. Elo, S. Moisio, R. Kinos, J. Vilkki, and A. Mäki-Tanila. 2001. Mapping of multiple quantitative trait loci by simple regression in half-sib designs. J. Anim. Sci. 79:616-622.

Felius, M. 1995. Encyclopedia of Cattle Breeds. Misset, Doetinchem, the Netherlands.

Georges, M., D. Nielsen, M. Mackinnon, A. Mishra, R. Okimoto, A. T. Pasquino, L. S. Sargeant, A. Sorensen, M. R. Steele, X. Zhao, J. E. Womack, and I. Hoeschele. 1995. Mapping quantitative trait loci controlling milk production in dairy cattle by exploiting progeny testing. Genetics 139:907-920

Gomez-Raya, L., H. Klungland, D. I. Våge, I. Olsaker, E. Fimland, G. Klemetsdal, K. Rønningen, and S. Lien. 1998. Mapping QTL for milk production traits in Norwegian Dairy Cattle. Proc. 6th World Congr. Genet. Appl. Livest. Prod., Armidale, Australia 26:429-432.

Green, P., K. Falls, and S. Crooks. 1990. Documentation for CRIMAP, version 2.4. Washington University School of Medicine, St. Louis, Mo., USA. 
Grisart, B., W. Coppieters, F. Farnir, L. Karim, C. Ford, P. Berzi, N. Cambisano, M. Mni, S. Reid, P. Simon, R. Spelman, M. Georges, and R. Snell. 2001. Positional candidate cloning of a QTL in dairy cattle: Identification of a missense mutation in the bovine DGAT1 gene with major effect on milk yield and composition. Genome Res. 12:222-231.

Heyen, D. W., J. I. Weller, M. Ron, M. Band, J. E. Beever, E. Feldmesser, Y. Da, G. R. Wiggans, P. M. VanRaden and H. A. Lewin. 1999. A genome scan for QTL influencing milk production and health traits in dairy cattle. Physiol. Genomics 1:165-175.

Kappes, S. M., J. W. Keele, R. T. Stone, R. A. McGraw, and T. S. Sonstegard. 1997. A second-generation linkage map of the bovine genome. Genome Res. 7:235-249.

Klungland, H., A. Sabry, B. Heringstad, H. G. Olsen, L. Gomez-Raya, D. I. Våge, I. Olsaker, J. Ødegård, G. Klemetsdal, N. Schulman, J. Vilkki, A. Karlsen, J. Ruane, M. Aasland, K. Rønningen, and S. Lien. 2001. Quantitative trait loci affecting clinical mastitis in cattle. Mamm. Genome 12:837-842.

Kühn, C., R. Weikard, T. Goldammer, S. Grupe, I. Olsaker, and M. Schwerin. 1996. Isolation and application of chromosome 6 specific microsatellite markers for detection of QTL for milk-production traits. J. Anim. Breed. Genet. 113:355-362.

Kühn, C., G. Freyer, R. Weikard, T. Goldammer, and M. Schwerin. 1999. Detection of QTL for milk production traits in cattle by application of a specifically developed marker map of BTA6. Anim. Genet. 30:333-340.

Lien, S., L. Gomez-Raya, T. Steine, E. Fimland, and S. Rogne. 1995. Associations between casein haplotypes and milk yield traits. J. Dairy Sci. 78:2047-2056.

Lipkin, E., M. O. Mosig, A. Darvasi, E. Ezra, A. Shalom, A. Friedman and M. Soller. 1998. Quantitative trait locus mapping in dairy cattle by means of selective milk DNA pooling using dinucleotide microsatellite markers: analysis of milk protein percentage. Genetics 149:1557-1567.

Looft, C., N. Reinsch, C. Karall-Albrecht, S. Paul, M. Brink, H. Thomsen, G. Brockmann, C. Kühn, M. Schwerin, and E. Kalm. 2001. A mammary gland EST showing linkage disequilibrium to a milk production QTL on bovine chromosome 14. Mamm. Genome 12:646-650.

Mäki-Tanila, A., D. J. de Koning, K. Elo, S. Moisio, R. Velmala, and J. Vilkki. 1998. Mapping of multiple quantitative trait loci by regression in half sib designs. Proc. 6th World Congr. Genet. Appl. Livest. Prod., Armidale, Australia 26:269-272.

Meuwissen, T. H. E., A. Karlsen, S. Lien, I. Olsaker, and M. E. Goddard. Fine mapping of a quantitative trait locus for twinning rate using combined linkage and linkage disequilibrium mapping. Genetics (in press).
Mosig, M. O., E. Lipkin, G. Khutoreskaya, E. Tchourzyna, M. Soller, and A. Friedmann. 2001. A whole genome scan for quantitative trait loci affecting milk protein percentage in Israeli-Holstein cattle, by means of selective milk DNA pooling in a daughter design, using an adjusted false discovery rate criterion. Genetics 157:1683-1698.

Nadesalingam, J., Y. Plante, and J. P. Gibson. 2001. Detection of QTL for milk production on chromosomes 1 and 6 of Holstein cattle. Mamm. Genome 12:27-31.

Riquet, J., W. Coppieters, N. Cambisano, J. J. Arranz, P. Berzi, S. Davis, B. Grisart, F. Farnir, L. Karim, M. Mni, P. Simon, J. Taylor, P. Vanmanshoven, D. Wagenaar, J. E. Womack, and M. Georges. 1999. Fine-mapping of quantitative trait loci by identity by descent in outbred populations: Application to milk production in dairy cattle. Proc. Natl. Acad. Sci., USA 96:9252-9257.

Ron, M., D. Kliger, E. Feldmesser, E. Seroussi, E. Ezra, and J. I. Weller. 2001. Multiple quantitative trait locus analysis of bovine chromosome 6 in the Israeli Holstein population by daughter design. Genetics 159:727-735.

Spelman, R. J., W. Coppieters, L. Karim, J. A. M. van Arendonk, and H. Bovenhuis. 1996. Quantitative trait loci analysis for five milk production traits on chromosome 6 in the Dutch Holstein-Friesian population. Genetics 144:1799-1808.

van Raden, P. M. and G. R. Wiggans. 1991. Derivation, calculation and use of national animal-model information. J. Dairy Sci. 74:2737-2746.

Velmala, R. J., H. J. Vilkki, K. T. Elo, D. J. de Koning, and A. V. Mäki-Tanila. 1999. A search for quantitative trait loci for milk production traits on chromosome 6 in Finnish Ayrshire cattle. Anim. Genet. 30:136-143.

Visscher, P. M., R. Thompson, and C. S. Haley. 1996. Confidence intervals in QTL mapping by bootstrapping. Genetics 143:1013-1020.

Våge D. I., I. Olsaker, H. Klungland, L. Gomez-Raya, and S. Lien. 2000. A male genetic map designed for quantitative trait loci mapping in Norwegian Dairy Cattle. Acta Agric. Scand. 50:56-63.

Weikard, R., T. Goldammer, C. Kühn, W. Barendse, and M. Schwerin. 1997. Targeted development of microsatelite markers from the defined region of bovine chromosome 6q21-31. Mamm. Genome 8:836-840.

Weller, J. I., Y. Kashi, and M. Soller. 1990. Power of daughter and granddaughter designs for determining linkage between marker loci and quantitative trait loci in dairy cattle. J. Dairy Sci. 73:2525-2537.

Zhang, Q., D. Boichard, I. Hoeschele, C. Ernst, A. Eggen, B. Murkve, M. Pfister-Genskow, L. A. Witte, F. E. Grignola, P. Uimari, G. Thaller, and M. D. Bishop. 1998. Mapping quantitative trait loci for milk production and health of dairy cattle in a large outbred pedigree. Genetics 149:1959--1973. 